\title{
CORRIGENDUM
}

\section{Connecting Early Neolithic worlds: excavating Mala (Nova) Pećina in Dalmatian Zagora, Croatia-CORRIGENDUM}

\author{
K. Trimmis \& I. Drnić
}

https://doi.org/10.15184/aqy.2018.57, Published by Cambridge University Press, 24 April 2018.

In the article by Trimmis and Drnić (2018), the caption for Figure 2 contained two spelling errors. The correct caption is as follows: Figure 2. The plan of the cave. Designed by T. Terezic and modified by M. Mađerić.

\section{References}

Trimmis, K. \& I. Drnić. 2018. Connecting Early Neolithic worlds: excavating Mala (Nova) Pećina in Dalmatian Zagora, Croatia. Antiquity Project Gallery 92(362). https://doi.org/10.15184/aqy.2018.57 